University of Wollongong

Research Online

Faculty of Engineering - Papers (Archive)

Faculty of Engineering and Information

Sciences

$1-1-2009$

\title{
Observation of Precipitation Evolution in Fe-Ni-Mn-Ti-Al Maraging Steel by Atom Probe Tomography
}

E V. Pereloma

University of Wollongong, elenap@uow.edu.au

R.A. Stohr

Monash University

M.K Miller

Oak Ridge Nat Lab, USA

S P. Ringer

University of Sydney

Follow this and additional works at: https://ro.uow.edu.au/engpapers

Part of the Engineering Commons

https://ro.uow.edu.au/engpapers/2885

\section{Recommended Citation}

Pereloma, E V.; Stohr, R.A.; Miller, M.K; and Ringer, S P.: Observation of Precipitation Evolution in Fe-Ni-MnTi-Al Maraging Steel by Atom Probe Tomography 2009, 3069-3075.

https://ro.uow.edu.au/engpapers/2885

Research Online is the open access institutional repository for the University of Wollongong. For further information contact the UOW Library: research-pubs@uow.edu.au 


\title{
Observation of Precipitation Evolution in Fe-Ni-Mn-Ti-Al Maraging Steel by Atom Probe Tomography
}

\author{
E.V. PERELOMA, R.A. STOHR, M.K. MILLER, and S.P. RINGER \\ We describe the full decomposition sequence in an Fe-Ni-Mn-Ti-Al maraging steel during \\ isothermal annealing at $550{ }^{\circ} \mathrm{C}$. Following significant pre-precipitation clustering reactions \\ within the supersaturated martensitic solid solution, $(\mathrm{Ni}, \mathrm{Fe})_{3} \mathrm{Ti}$ and $(\mathrm{Ni}, \mathrm{Fe})_{3}(\mathrm{Al}, \mathrm{Mn})$ precipi- \\ tates eventually form after isothermal aging for $\sim 60$ seconds. The morphology of the $(\mathrm{Ni}, \mathrm{Fe})_{3} \mathrm{Ti}$ \\ particles changes gradually during aging from predominantly plate-like to rod-like, and, \\ importantly, $\mathrm{Mn}$ and $\mathrm{Al}$ were observed to segregate to these precipitate/matrix interfaces. The \\ $(\mathrm{Ni}, \mathrm{Fe})_{3}(\mathrm{Al}, \mathrm{Mn})$ precipitates occurred at two main locations: uniformly within the matrix and \\ at the periphery of the $(\mathrm{Ni}, \mathrm{Fe})_{3} \mathrm{Ti}$ particles. We relate this latter mode of precipitation to the \\ $\mathrm{Mn}$-Al segregation.
}

DOI: $10.1007 / \mathrm{s} 11661-009-9993-\mathrm{z}$

(C) The Minerals, Metals \& Materials Society and ASM International 2009

\section{INTRODUCTION}

FOR several decades, maraging steels have been used in the military, power, and other commercial industries due to their combination of high strength and toughness, particularly at elevated temperatures. The most commonly used maraging steel compositions are based on 18 wt pct $\mathrm{Ni}$ with significant levels of $\mathrm{Co}$ (8 to $13 \mathrm{wt}$ pct). These elements make these steels rather expensive, ${ }^{[1-3]}$ and, as a result, a new class of Co-free maraging steels has emerged that contain $\mathrm{Fe}, \mathrm{Ni}$, Mo, and $\mathrm{Ti}^{[-8]}$ The improved properties achieved in these newer steels are associated with the formation of $\mathrm{Ni}_{3} \mathrm{Ti}$ and $\mathrm{Fe}_{2}(\mathrm{Mo}, \mathrm{Ti})$ precipitates, which strengthen the alloys through the operation of Orowan-type mechanisms. The morphology of the $\mathrm{Ni}_{3} \mathrm{Ti}$ particles was found to be needle-like, ${ }^{[7,9-12]}$ plate-like, ${ }^{[1]}$ or rod-like. ${ }^{[4,7]}$ In addition, unidentified spherical precipitates were detected in the matrix. ${ }^{[7]}$ However, heat treatments of several hours duration are required to achieve the maximum agehardening response in these steels. ${ }^{[7,8]}$ Therefore, Mn additions were introduced, as this element was found to accelerate the age-hardening process and also reduce the required levels of the more expensive $\mathrm{Ni}$ additions. ${ }^{[12-16]}$ Remarkably, the best combination of strength and ductility was achieved in a Fe-Ni-Mn-Ti-Al maraging

E.V. PERELOMA, Professor of Physical Metallurgy and Director of the BlueScope Steel Metallurgy Centre, is with the School of Mechanical, Materials and Mechatronics Engineering, University of Wollongong, NSW 2522, Wollongong, Australia. Contact e-mail: elenap@uow.edu.au R.A. STOHR, Engineer, formerly with the Department of Materials Engineering, Monash University, Clayton, VIC 3800, Australia, is with Esso Australia, 12 Riverside Quay, Southbank, Melbourne, VIC 3000, Australia. M.K. MILLER, Distinguished R\&D Staff Member, is with the Materials Science and Technology Division, Oak Ridge National Laboratory, Oak Ridge, TN 37831-6136. S.P. RINGER, Professor and Director, is with the Australian Key Centre for Microscopy \& Microanalysis, The University of Sydney, Sydney, NSW 2006 Australia.

Manuscript submitted August 31, 2008.

Article published online September 23, 2009 steel after very short aging treatments at $550{ }^{\circ} \mathrm{C}$ for as little as 5 to 15 seconds. ${ }^{[16]}$ Approximately, $50 \mathrm{pct}$ of the total strength increment from age hardening was achieved during these short aging treatments. Careful transmission electron microscopy (TEM) studies revealed no evidence for discrete second-phase precipitates, suggesting that the strengthening occurred from alternate mechanisms within the solid solution. This was further supported by our atom probe studies, which revealed preferred solute-solute interactions and strong atomic clustering phenomena during these early stages. We proposed that a cluster-strengthening mechanism was operative in order to achieve the high toughness. ${ }^{[16]}$ Subsequent aging did eventually lead to precipitation reactions, and, according to our TEM observations, ${ }^{[16]}$ initially fine $\mathrm{Ni}_{3}(\mathrm{Ti}, \mathrm{Al})(3.5 \pm 0.6-\mathrm{nm}$ thick and $9.5 \pm 1.5$-nm long) needle-like particles were distributed uniformly within the martensite laths. At later stages of aging, these coarsen $(6.2 \pm 0.4-\mathrm{nm}$ thick and $23 \pm 1-\mathrm{nm}$ long) and their distribution becomes inhomogeneous, with a significant preference for precipitation at lath martensite boundaries. These changes were accompanied by a further increase in strength and decrease in ductility. At the same time, the formation of reverted austenite at prior austenite and lath martensite boundaries became evident.

In this article, we turn our attention to the later stages of aging where there is a need for consistent information on the composition and morphology of precipitates, as studies of these types of alloys aged for longer times suggest that the properties are also consistent with Orowan-type mechanisms. ${ }^{[15]}$ In seeking to clarify the nature of precipitation at these later stages, we have used electron microscopy in conjunction with atom probe. It is noteworthy that all previous atom probe studies were performed with one-dimensional or threedimensional atom probe field ion microscopes. ${ }^{[6,15,16]}$ The recently developed local electrode atom probe ${ }^{[17,18]}$ is more advanced in that it allows collection of data from much larger volumes of material in a shorter 
period of time. This is important in evaluating precipitate microstructures. The application of statistical methods to the larger volume of materials enables a more accurate quantification of the features in the microstructure.

\section{EXPERIMENTAL}

A small steel ingot (Fe-20.1Ni-1.8Mn-1.6Ti-0.59Al0.04Si-0.01C with $\mathrm{P}$ and $\mathrm{S}<0.001$ (wt pet)) was solution heat treated at $1100{ }^{\circ} \mathrm{C}$ for 12 hours. Thin slices of $\sim 0.4-\mathrm{mm}$ thickness were cut, immersed in alumina powder, and austenitized in a furnace at $1050{ }^{\circ} \mathrm{C}$ for 1 hour and then water quenched. They were immediately immersed into liquid nitrogen for 360 seconds in order to complete the martensite transformation. In the as-quenched condition, the microstructure contained martensite with $\sim 5$ pct retained austenite in the form of thin layers between the martensite laths. ${ }^{[1,16]}$ The samples were aged in a salt bath for 5 to 3600 seconds at $550{ }^{\circ} \mathrm{C}$. Needle-shaped atom probe specimens were prepared with a standard two-stage electropolishing procedure. ${ }^{[19]}$ Atom probe experiments were performed with local electrode atom probes (LEAP)* at Oak Ridge

*LEAP is a trademark of Imago Scientific Instruments Corp., Madison, WI.

National Laboratory and at The University of Sydney. The LEAP was operated at a pulse repetition rate of $200 \mathrm{kHz}$, a pulse fraction of 0.2 , and a sample temperature of 60 or $80 \mathrm{~K}$. Isoconcentration surfaces were used for visualization of the precipitates. The compositions of precipitates were determined from the selected volumes with background noise subtraction. The maximum separation envelope method ${ }^{[19]}$ with a maximum separation distance between atoms of interest of $0.5 \mathrm{~nm}$ and a grid spacing of $0.1 \mathrm{~nm}$ was used to identify clusters in the samples aged for 5 seconds. The atomic composition of such regions was calculated from the number of atoms of each type forming a cluster or a particle as determined by the maximum separation envelope method. As output of the maximum separation envelope program, the size of the feature is given by the radius of gyration $\left(l_{g}\right)$, which is smaller than what might be considered the actual physical extent. That size might be better represented by the Guinier radius $\left(r_{G}\right)$ given by the following equation: ${ }^{[19]}$

$$
r_{G}=\sqrt{\frac{5}{3}} \times l_{g}
$$

\section{RESULTS AND DISCUSSION}

After aging for 5 seconds, the early stages of decomposition of martensite were evident from the formation of clusters containing various proportions of $\mathrm{Ti}, \mathrm{Ni}, \mathrm{Al}$, and Mn (Figure 1(a)). In this article, clusters are defined
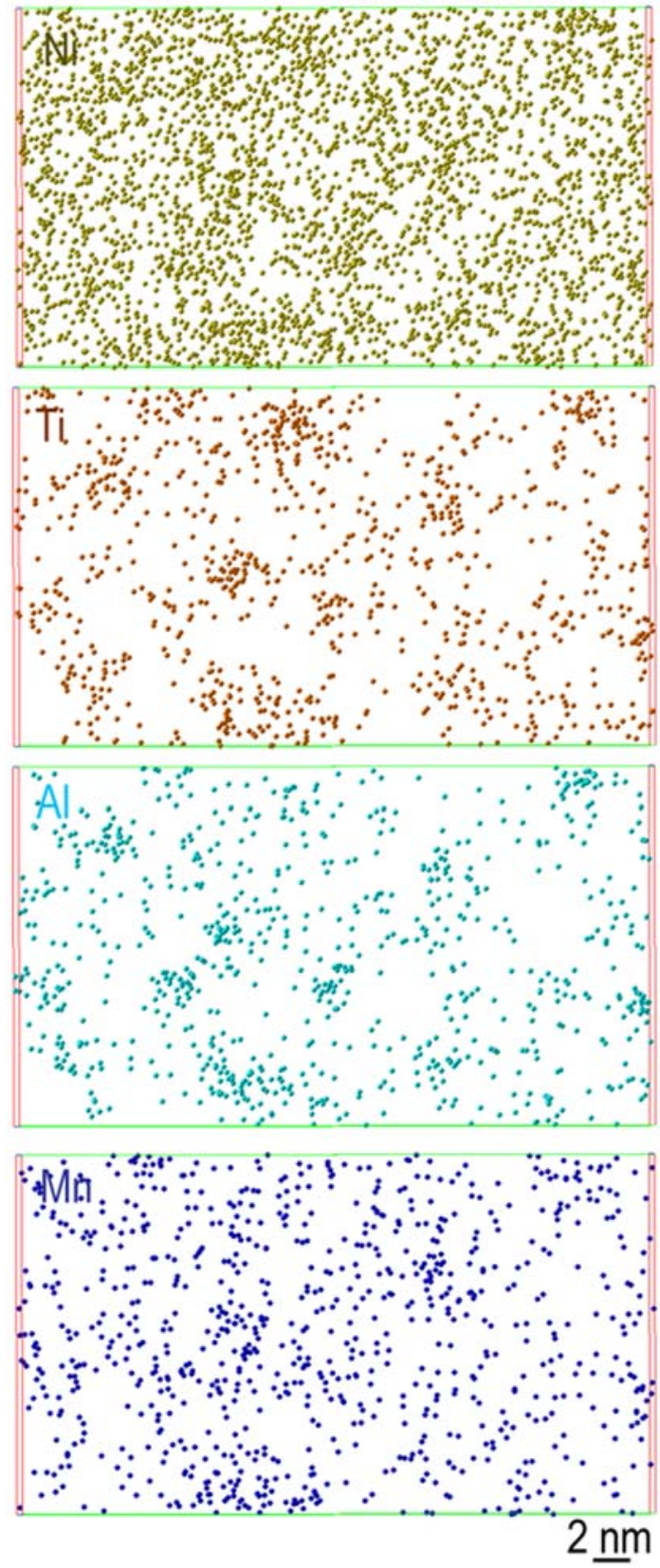

Fig. 1-Selected $\mathrm{Ni}, \mathrm{Ti}, \mathrm{Al}$, and $\mathrm{Mn}$ atom maps showing formation of clusters in the martensite after $5 \mathrm{~s}$ aging. The dimensions of the selected volume are $17.7 \times 31.3 \times 2.0 \mathrm{~nm}$.

as nonrandom close arrangements of atoms within the volume, which still contains visible crystallographic arrangement of matrix Fe atoms. On the other hand, precipitates are defined as arrangements of atoms exhibiting their own crystallographic structure and chemistry, distinct from that of the matrix. Based on cluster composition analyses with the maximum separation method, two clearly distinct groups of clusters were identified: (1) Mn-rich clusters containing 60 to 100 pet of $\mathrm{Mn}$ and (2) $\mathrm{Ti}+\mathrm{Al}$-rich clusters with varying composition of each element from 15 to 70 pct (Table I, Figure 2). The $\mathrm{Ni}$ and $\mathrm{Fe}$ atoms were present in both groups of clusters. The approximate number of 
Table I. Characterization of Clusters

\begin{tabular}{|c|c|c|c|c|c|c|c|c|}
\hline \multirow[b]{2}{*}{ Clusters } & \multicolumn{8}{|c|}{ Composition, At. Pct } \\
\hline & $\mathrm{Fe}$ & $\mathrm{Ni}$ & $\mathrm{Mn}$ & $\mathrm{Ti}$ & $\mathrm{Al}$ & $r_{G}, \mathrm{~nm}$ & $\begin{array}{l}\text { Number of } \\
\text { Ions per Cluster }\end{array}$ & Number of Clusters \\
\hline \multirow[t]{3}{*}{ Mn rich } & 0 to 9 & 0 to 9 & 90 to 100 & - & - & $1.0 \pm 0.2$ & 20 to 74 & 102 \\
\hline & 0 to 18 & 0 to 12.5 & 78 to 90 & - & - & $1.0 \pm 0.2$ & 22 to 146 & 112 \\
\hline & 0 to 11 & 0 to 5 & 65 to 78 & - & - & $1.0 \pm 0.3$ & 26 to 90 & 28 \\
\hline \multirow[t]{4}{*}{$\mathrm{Ti}+\mathrm{Al}$ rich } & 25 to 36 & 3 to 18 & - & 16 to 39 & 17 to 47 & $1.4 \pm 0.3$ & 28 to 441 & 27 \\
\hline & 4 to 24 & 0 to 22 & - & 16 to 72 & 14 to 71 & $1.2 \pm 0.2$ & 22 to 177 & 529 \\
\hline & 2 to 4 & 0 to 11 & - & 17 to 75 & 21 to 72 & $1.04 \pm 0.8$ & 23 to 54 & 55 \\
\hline & 0 & 0 to 11 & - & 18 to 80 & 21 to 74 & $0.8 \pm 0.1$ & 20 to 62 & 23 \\
\hline
\end{tabular}

Note: In some Mn-rich clusters, traces of Ti and Al were present, whereas in Ti+ Al-rich clusters, some traces of Mn were detected.

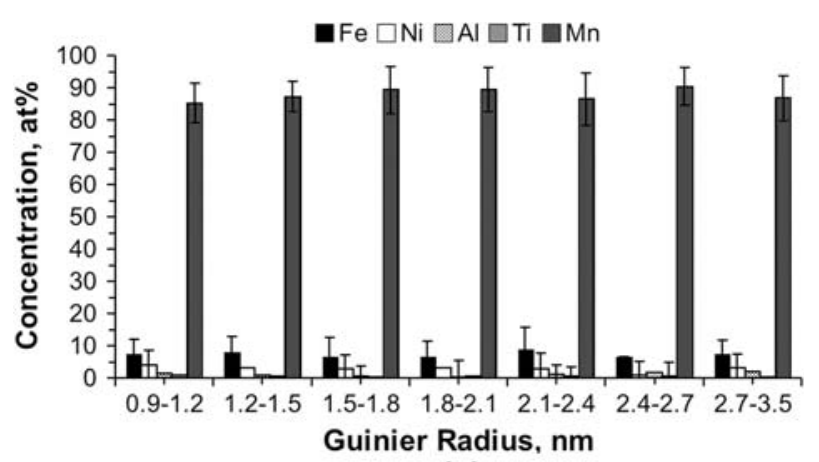

(a)

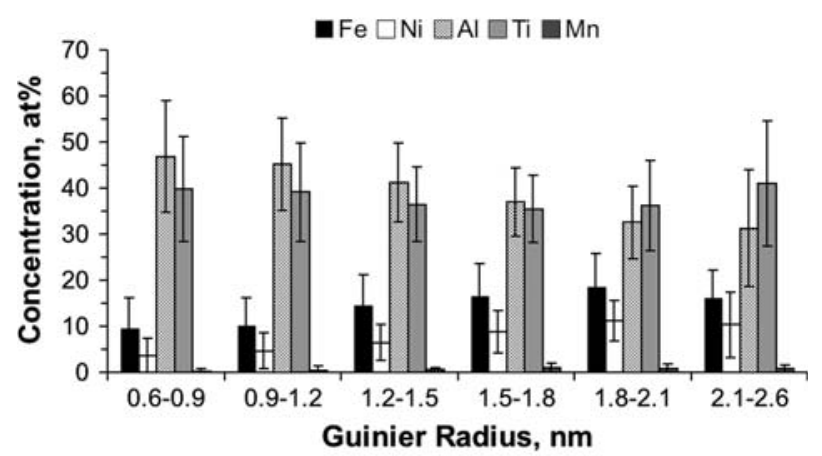

(b)

Fig. 2-Variation of cluster composition with size: (a) Mn-rich and (b) $\mathrm{Ti}+\mathrm{Al}$-rich clusters.

ions per cluster varied from 20 to 441 . As the $\mathrm{Mn}$, Ti, and $\mathrm{Al}$ concentrations varied continuously in the compositions of clusters, the clusters were divided into groups based on the Fe content (Table I). The number of clusters per each group ranged from 23 to 529 . Although there was a wide variation in composition of the Mn-rich clusters, their average size remained approximately constant (1 nm) (Figure 2(b)). At the same time, the composition of $\mathrm{Ti}+\mathrm{Al}$-rich clusters varied with size in a similar manner to the composition of $\mathrm{Fe}+\mathrm{C}$ clusters observed during the decomposition of martensite in the TRIP steels; ${ }^{[20]}$ e.g., with the decrease in cluster size, the Fe content also decreased. It is well known that the maximum separation distance envelope method aggressively removes the matrix atoms. The envelope algorithm will only remove solvent atoms from the surface of the particle and not the interior. Thus, the maximum separation envelope method may overestimate the solute content of the finest clusters $(\leq 1 \mathrm{~nm})$ by $\sim 25 \mathrm{pct}$ in which there is a high proportion of surface to interior atoms. The standard deviations given in Table I are based only on the experimental data obtained by the envelope method without taking into account the inherent overestimation of solute content in fine clusters. Although it is clear that, in $\mathrm{Ti}+\mathrm{Al}$-rich clusters, both $\mathrm{Fe}$ and $\mathrm{Ni}$ concentrations gradually increase with an increase in cluster size (Figure 2(a)); even on reaching $\sim 2$-nm Guinier radius, the composition of clusters remains nonstochiometric $\left(\sim(\mathrm{Fe}, \mathrm{Ni})(\mathrm{Ti}, \mathrm{Al})_{2}\right)$. The observed clustering supports the proposal based on Mössbauer spectroscopy data that the accelerated effect of $\mathrm{Mn}$ on $\mathrm{Ni}_{3} \mathrm{Ti}$ precipitation in maraging steels is by displacing Ti from solid solution and preferential formation of Fe-Mn bonds. ${ }^{[14]}$ However, faster diffusion of $\mathrm{Ti}$ and $\mathrm{Al}$ at aging temperature compared to the diffusion of $\mathrm{Ni}, \mathrm{Mn}$, and Fe (Table II) could also account for the observed composition of clusters. A more detailed discussion of clustering was given elsewhere. ${ }^{[16]}$

Although the formation of precipitates was detected in this steel after aging for $\sim 60$ seconds at $550{ }^{\circ} \mathrm{C},{ }^{[16]}$ the focus of this article is on the precipitation behavior during later stages of aging. Representative atom maps after aging for 600 seconds are shown in Figure 3. It is clear that two precipitate morphologies are present: plate and spheroidal. Analysis of the plate-shaped precipitates (Table III) has shown that they consist predominantly of $\mathrm{Fe}+\mathrm{Ni}+\mathrm{Ti}$ atoms with some traces of $\mathrm{Al}$ and $\mathrm{Mn}$, whereas the spheroidal precipitates consist of $\mathrm{Ni}+\mathrm{Fe}+\mathrm{Al}+\mathrm{Mn}$ atoms. Their compositions were found to be close to $(\mathrm{Ni}, \mathrm{Fe})_{3} \mathrm{Ti}$ and $(\mathrm{Ni}, \mathrm{Fe})_{3}(\mathrm{Al}, \mathrm{Mn})$ stoichiometries, respectively. Some of the plate-shaped particles exhibited an increase in thickness toward lath shape, but with a slightly rounded tip.

After extending the aging to 3600 seconds, the microstructure also included some coarsened $\mathrm{Ni}+\mathrm{Mn}+\mathrm{Al}$ precipitates that exhibited a modified aspect ratio toward discs and small rods (Figure 4 and Table III), presumably as part of the coarsening reaction. At the same time, $(\mathrm{Ni}, \mathrm{Fe})_{3} \mathrm{Ti}$ precipitates have shown two types of morphology: plate-like and rod-like (Figure 5). 
Table II. Diffusion Coefficients Data for Self-Diffusion and Solute Diffusion in $\alpha$-Fe

\begin{tabular}{llllll}
\hline Element & \multicolumn{1}{c}{ Fe } & \multicolumn{1}{c}{ Ni } & Mn & Ti & Al \\
\hline Diffusion coefficient, $D\left(\mathrm{~m}^{2} \mathrm{~s}^{-1}\right)$ & $1.1 \times 10^{-17}$ & $4.37 \times 10^{-17}$ & $7.2 \times 10^{-17}$ & $4.72 \times 10^{-18}$ & $7.69 \times 10^{-17}$ \\
Temperature range, ${ }^{\circ} \mathrm{C}$ & 550 & 550 & 700 & 675 & 550 \\
Reference & 21 & 21 & 22 & 23 & 21 \\
\hline
\end{tabular}

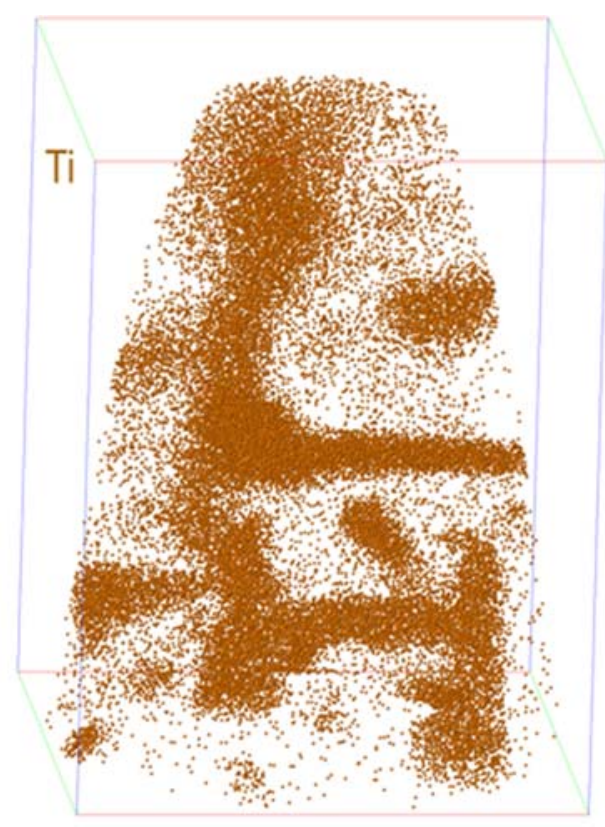

(a)

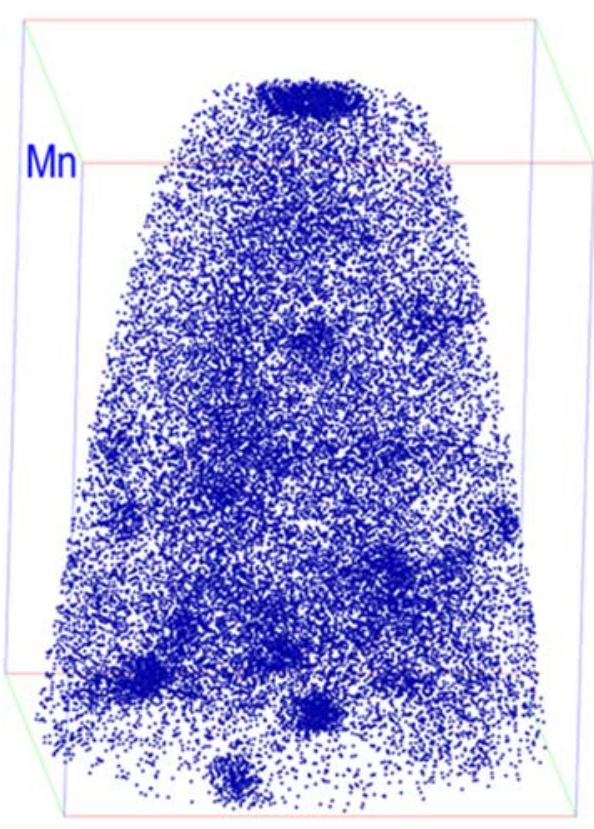

(c)

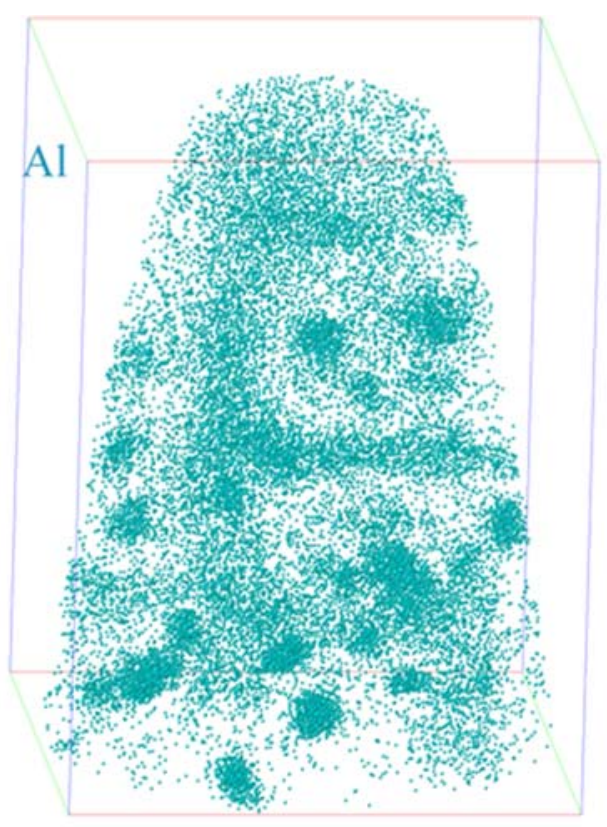

(b)

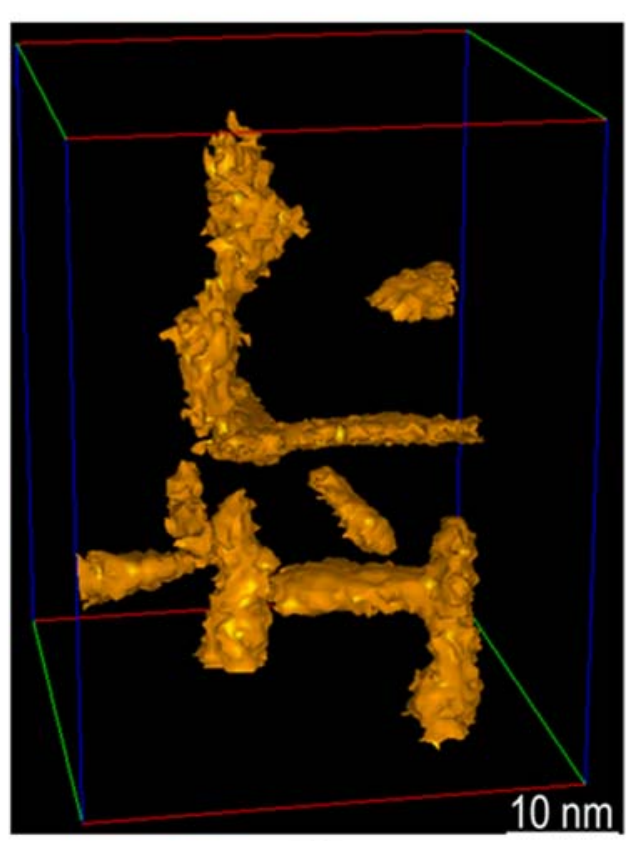

(d)

Fig. 3- (a) $\mathrm{Ti},(b) \mathrm{Al}$, and $(c) \mathrm{Mn}$ atom maps and $(d)$ corresponding 58 pct $(\mathrm{Ni}+\mathrm{Ti}+\mathrm{Al}+\mathrm{Mn})$ isoconcentration surfaces of the sample aged for $600 \mathrm{~s}$ showing plate-shaped and spheroidal precipitates.

We propose that the driving force for this transition in morphology is a change in the precipitate interfacial energy during growth.
An important feature in the samples treated for 3600 seconds is the enrichment of $\mathrm{Mn}$ and $\mathrm{Al}$ at the plate-shaped precipitate/matrix interface, as is clearly 

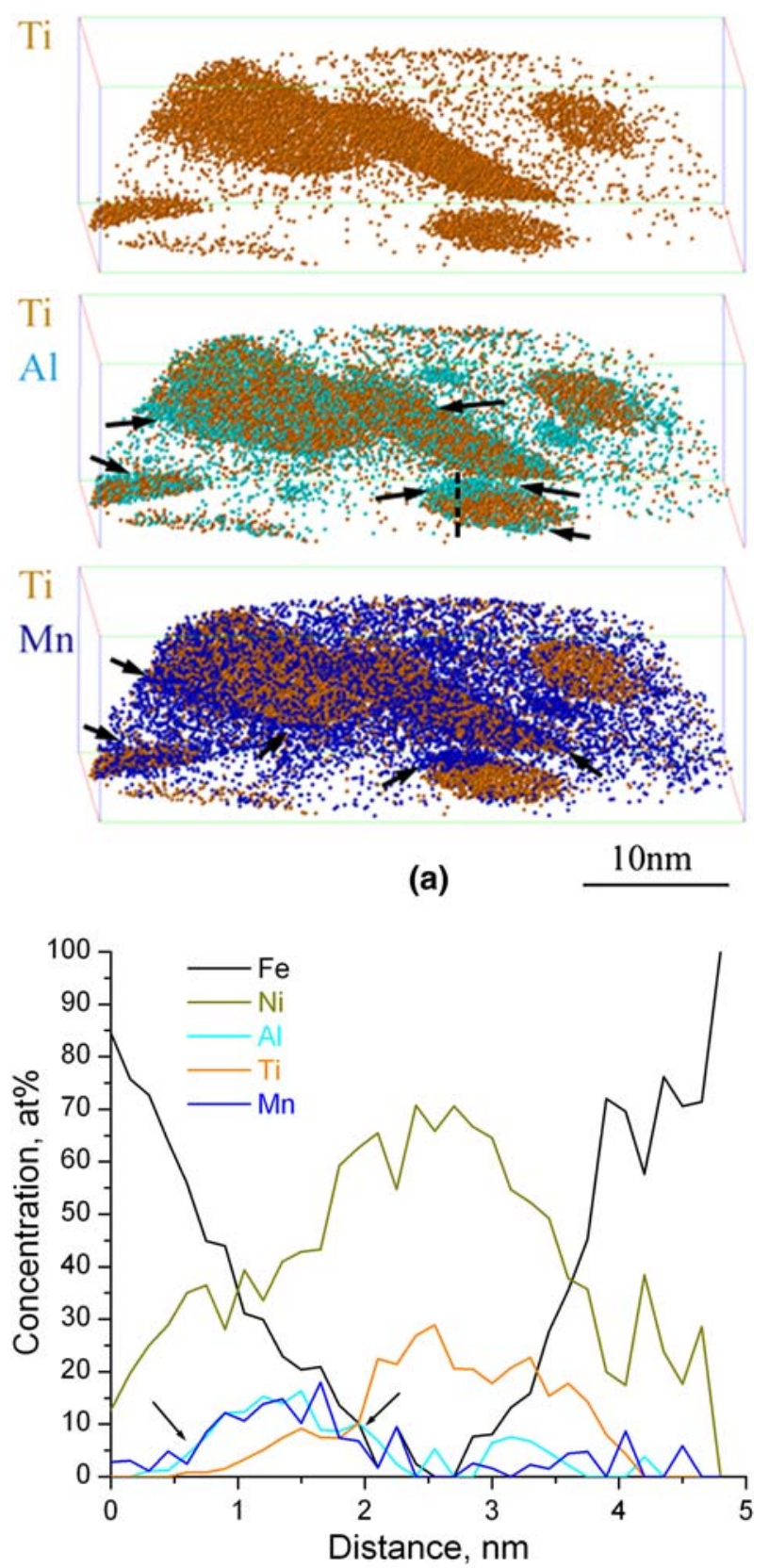

(b)

Fig. $4-$ (a) $\mathrm{Ti}, \mathrm{Ti}+\mathrm{Al}$, and $\mathrm{Ti}+\mathrm{Mn}$ atom maps showing precipitation in the sample aged for $3600 \mathrm{~s}$ at $550{ }^{\circ} \mathrm{C}$ and $(b)$ representative concentration profile across a $\sim(\mathrm{Ni}, \mathrm{Fe})_{3} \quad(\mathrm{Al}, \mathrm{Mn})$ nuclei on a $(\mathrm{Ni}, \mathrm{Fe})_{3} \mathrm{Ti}$ precipitate. Note that enrichment of $\mathrm{Al}$ and $\mathrm{Mn}$ to the plate/matrix interface and nucleation of $\sim(\mathrm{Ni}, \mathrm{Fe})_{3}(\mathrm{Al}, \mathrm{Mn})$ particle on the $(\mathrm{Ni}, \mathrm{Fe})_{3} \mathrm{Ti}$ plate are indicated by the arrows. The dashed line on the $\mathrm{Ti}+\mathrm{Al}$ atom map indicates the direction along which the concentration profile was taken.

seen in the $\mathrm{Ti}+\mathrm{Mn}$ and $\mathrm{Ti}+\mathrm{Al}$ atom maps shown in Figure 4(a). Concentration profiles across these interfaces also confirm this enrichment (Figure 4(b)). Specifically, the atom probe data demonstrate significantly higher $\mathrm{Mn}$ and $\mathrm{Al}$ concentration levels at the precipitate/ matrix interface than those for either the matrix or within the $(\mathrm{Fe}, \mathrm{Ni})_{3} \mathrm{Ti}$ particles. Compositions of these enriched regions, determined by selected volume
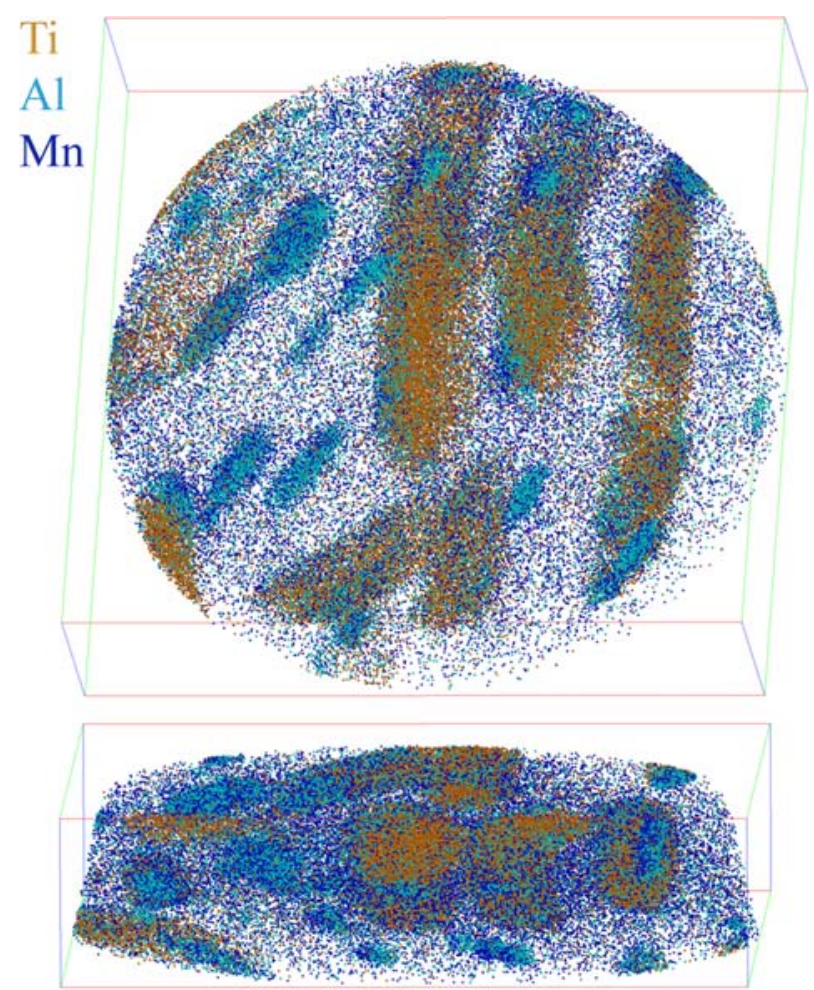

(a)

$\underline{10 \mathrm{~nm}}$

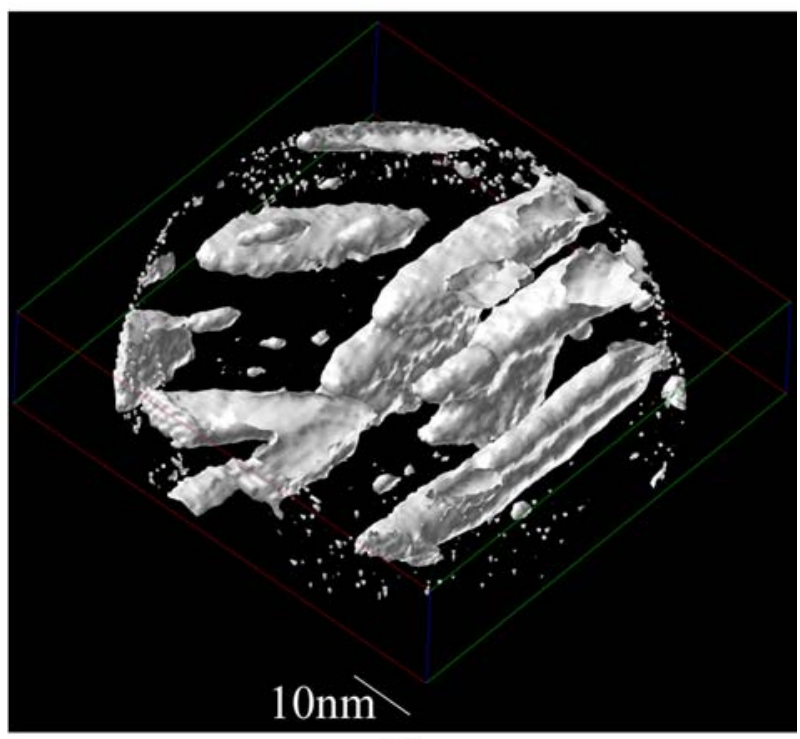

(b)

Fig. 5- (a) $\mathrm{Ti}+\mathrm{Mn}+\mathrm{Al}$ atom maps from two perpendicular directions showing the morphology of rod-shaped precipitates after $3600 \mathrm{~s}$ aging and $(b)$ corresponding 30 at. pct $(\mathrm{Ni}+\mathrm{Ti})$ isoconcentration surfaces. Some noise is evident on the surface of the analyzed volume.

analysis, are given in Table IV. In addition, evidence of heterogeneous nucleation of $\mathrm{Ni}+\mathrm{Mn}+\mathrm{Al}$ precipitation at both the plate- and rod-shaped $(\mathrm{Fe}, \mathrm{Ni})_{3} \mathrm{Ti}$ particles was observed in several instances. Here, we propose that the initial segregation of $\mathrm{Mn}$ and $\mathrm{Al}$ occurs at the precipitate/matrix interface, and when the segregant 
Table III. Characterization of Precipitation

\begin{tabular}{|c|c|c|c|c|c|c|}
\hline & \multicolumn{2}{|c|}{ After $600 \mathrm{~s}$ Aging } & \multicolumn{4}{|c|}{ After $3600 \mathrm{~s}$ Aging } \\
\hline & $(\mathrm{Ni}, \mathrm{Fe})_{3}(\mathrm{Al}, \mathrm{Mn})$ & $(\mathrm{Ni}, \mathrm{Fe})_{3} \mathrm{Ti}$ & $(\mathrm{Ni}, \mathrm{Fe})_{3}(\mathrm{Al}, \mathrm{Mn})$ & $\sim(\mathrm{Ni}, \mathrm{Fe})_{3}(\mathrm{Al}, \mathrm{Mn})$ & $\sim(\mathrm{Ni}, \mathrm{Fe})_{3} \mathrm{Ti}$ & $\sim(\mathrm{Ni}, \mathrm{Fe})_{3} \mathrm{Ti}$ \\
\hline $\mathrm{Fe}$, at. pct & $27 \pm 5$ & $9 \pm 3$ & $51 \pm 6$ & $26 \pm 1$ & $15 \pm 0.1$ & $19 \pm 0.1$ \\
\hline $\mathrm{Ni}$, at. pet & $40 \pm 6$ & $60 \pm 3$ & $22 \pm 1$ & $43 \pm 1$ & $51 \pm 1$ & $52 \pm 0.1$ \\
\hline $\mathrm{Ti}$, at. pet & $2 \pm 1$ & $22 \pm 2$ & $0.3 \pm 0.4$ & $0.2 \pm 0.1$ & $19 \pm 0.4$ & $17 \pm 0.1$ \\
\hline $\mathrm{Al}$, at. pct & $17 \pm 3$ & $3.1 \pm 0.6$ & $15 \pm 4$ & $20 \pm 2$ & $5 \pm 0.1$ & $4 \pm 0.1$ \\
\hline Mn, at. pct & $10 \pm 4$ & $1.7 \pm 0.6$ & $8 \pm 3$ & $8.1 \pm 0.1$ & $3 \pm 0.5$ & $2 \pm 0.1$ \\
\hline \multicolumn{7}{|l|}{ Size, nm } \\
\hline$x$ & $4.4 \pm 0.7$ & $9 \pm 1$ & $4 \pm 2$ & $5 \pm 1$ & $7 \pm 0.7$ & $10 \pm 1$ \\
\hline$y$ & $3.7 \pm 0.8$ & $3 \pm 1$ & $2 \pm 0.7$ & $4 \pm 1$ & $3 \pm 0.6$ & $8 \pm 2$ \\
\hline$z$ & $5.3 \pm 0.3$ & $16 \pm 4$ & $5 \pm 2$ & $10 \pm 2$ & $13 \pm 1$ & $17 \pm 5$ \\
\hline Morphology & spheroidal & plate-shaped & disc-shaped & rod-shaped & plate-shaped & rod-shaped \\
\hline $\begin{array}{l}\text { Number density, } \\
\text { per } \mathrm{m}^{3}\end{array}$ & $(4 \pm 3) \times 10^{23}$ & $(2 \pm 1) \times 10^{23}$ & $(2 \pm 1) \times 10^{23}$ & $(2 \pm 1) \times 10^{23}$ & $(3 \pm 1) \times 10^{23}$ & $(1 \pm 0.5) \times 10^{23}$ \\
\hline
\end{tabular}

Table IV. Characterization of Particle/Interface Segregation and Nucleation

\begin{tabular}{llcc}
\hline & After $600 \mathrm{~s}$ Aging & \multicolumn{2}{c}{ After 3600 s Aging } \\
\cline { 2 - 4 } & Nucleation of $(\mathrm{Ni}, \mathrm{Fe})_{3}(\mathrm{Al}, \mathrm{Mn})$ & $\begin{array}{c}\text { Nucleation of } \\
(\mathrm{Ni}, \mathrm{Fe})_{3}(\mathrm{Al}, \mathrm{Mn})\end{array}$ & $\begin{array}{c}\text { Interface Enrichment } \\
(\mathrm{Ni}, \mathrm{Fe})_{3}(\mathrm{Al}, \mathrm{Mn})\end{array}$ \\
\hline Fe, at. pct & $27 \pm 7$ & $31 \pm 3$ & $43 \pm 3$ \\
$\mathrm{Ni}$, at. pct & $41 \pm 3$ & $39 \pm 1$ & $35 \pm 2$ \\
Ti, at. pct & $3.6 \pm 0.4$ & $4 \pm 2$ & $6 \pm 2$ \\
Al, at. pct & $15 \pm 2$ & $8 \pm 2$ & $9 \pm 2$ \\
Mn, at. pct & $8 \pm 1$ & $5 \pm 1$ & $5 \pm 1$ \\
Size, nm & $6.5 \pm 0.4$ & $2 \pm 1$ & $5 \pm 1$ \\
$x$ & $5 \pm 1$ & $8 \pm 2$ & $3 \pm 1$ \\
$y$ & $5 \pm 1$ & $(9 \pm 7) \times 10^{22}$ & $19 \pm 4$ \\
$z$ & $(4 \pm 1) \times 10^{22}$ & $(3 \pm 1) \times 10^{22}$ \\
Number density, per $\mathrm{m}^{3}$ & & & 1 \\
\hline
\end{tabular}

composition and free energy have reached critical values, heterogeneous nucleation of $\mathrm{Ni}+\mathrm{Mn}+\mathrm{Al}$ particles occurs. The compositions of these heterogeneously nucleated precipitates are similar to the spheroidal or small rod-shaped particles, which were observed in the matrix. It was previously suggested ${ }^{[16]}$ that their nucleation took place during the early stages of aging at both intersections of dislocations and at clusters.

It is interesting to consider the nature of the observed preferential segregation of Al and Mn atoms at the precipitate/matrix interface, since this has an enabling role in the heterogeneous nucleation of $\mathrm{Ni}+\mathrm{Mn}+\mathrm{Al}$ particles. In fact, the observed preferential segregation of $\mathrm{Al}$ and $\mathrm{Mn}$ atoms at the $(\mathrm{Fe}, \mathrm{Ni})_{3} \mathrm{Ti}$ precipitate/matrix interfaces is thought to be the result of nonequilibrium segregation of solute from the bulk. ${ }^{[24]}$ The kinetics of this segregation will be determined primarily by the volume diffusion of segregating species. However, out of all alloying elements, the diffusion rate is the highest for $\mathrm{Ti}$ (Table II) and the lowest for $\mathrm{Ni}$, whereas $\mathrm{Mn}$ and $\mathrm{Al}$ display comparable rates. This suggests that the thermodynamic affinity between $\mathrm{Al}$ and Mn plays a more important role in their cosegregation to the particle/ matrix interface than the relative rates of their diffusion. It is well known that the thermodynamic affinity between $\mathrm{Mn}$ and $\mathrm{Al}$ is high $^{[25,26]}$ and that $\mathrm{Mn}$ has a tendency to segregate preferentially to grain boundaries and other interfaces in steels. ${ }^{[27,28]}$ The observed formation of an Al-Mn-rich layer around the intermetallic $(\mathrm{Fe}, \mathrm{Ni})_{3} \mathrm{Ti}$ precipitates is similar to the formation of the $\mathrm{Al}_{8} \mathrm{Mn}_{5}$ layer on $\mathrm{Al}$-containing carbides in $\mathrm{Mg}-\mathrm{Al}$ alloys. ${ }^{[26]}$ Thus, we suggest that a thermodynamic driving force exists for the observed segregation of $\mathrm{Mn}$ and $\mathrm{Al}$ at the $(\mathrm{Fe}, \mathrm{Ni})_{3} \mathrm{Ti}$ precipitate/matrix interfaces due to the reduction in the interfacial free energy. Similar conclusions were drawn regarding the $\mathrm{Ni}$ and $\mathrm{Mn}$ segregation at the interface of $\mathrm{Cu}$-rich particles in a low-carbon steel. ${ }^{[29]}$

\section{CONCLUSIONS}

The decomposition of martensite in the Fe-Ni-Mn-TiAl steel during aging at $550{ }^{\circ} \mathrm{C}$ occurs by (1) a clustering stage, involving the formation of predominantly $\mathrm{Ti}+\mathrm{Al}$ and $\mathrm{Mn}+\mathrm{Fe}$ co-clusters after 5 seconds; (2) precipitation of plate-shaped $(\mathrm{Ni}, \mathrm{Fe})_{3} \mathrm{Ti}$ and spheroidal $(\mathrm{Ni}, \mathrm{Fe})_{3}(\mathrm{Al}, \mathrm{Mn})$ nanoscale particles after $\sim 60$ seconds aging; (3) enrichment of $\mathrm{Al}$ and $\mathrm{Mn}$ at the $(\mathrm{Ni}, \mathrm{Fe})_{3} \mathrm{Ti}$ particle/matrix interface; (4) secondary precipitation: heterogeneous nucleation of $\mathrm{Ni}+\mathrm{Mn}+\mathrm{Al}$ particles on the surface of $(\mathrm{Ni}, \mathrm{Fe})_{3} \mathrm{Ti}$ precipitates; and (5) progressive change of $(\mathrm{Ni}, \mathrm{Fe})_{3} \mathrm{Ti}$ precipitate morphology from plate-shaped to rod-shaped. 


\section{ACKNOWLEDGMENTS}

The authors thank K.F. Russell, ORNL, and T. Schambron, UOW, for technical assistance. Atom probe research at the Oak Ridge National Laboratory SHaRE User Facility was sponsored by the Scientific User Facilities Division, Basic Energy Sciences, United States Department of Energy. The authors also acknowledge the assistance from the AMMRF at the University of Sydney. This work was partially supported by the Australian Research Council.

\section{REFERENCES}

1. G.P. Miller and W.I. Mitchell: J. Iron Steel Inst., 1965, vol. 20, pp. 899-904.

2. R.F. Decker, J.T. Eash, and A.J. Goldman: Trans. ASM, 1962, vol. 55 , pp. $58-76$.

3. R.F. Decker and S. Floreen: in Maraging Steels: Recent Developments and Applications, R.K. Wilson, ed., TMS, Warrendale, PA, 1988, pp. 1-38.

4. V.K. Vasudevan, S.J. Kim, and C.M. Wayman: Metall. Trans. A, 1990, vol. 21A, pp. 2655-68.

5. P.P. Sinha, K.T. Tharian, K. Sreekumar, K.V. Nagarajan, and D.S. Sarma: Mater. Sci. Technol., 1998, vol. 14, pp. 1-9.

6. W. Sha, A. Cerezo, and G.D.W. Smith: Metall. Trans. A, 1993 , vol. 24A, pp. 1221-56.

7. Y. He, K. Yang, and W. Sha: Metall. Mater. Trans. A, 2005 , vol. 36A, pp. 2273-87.

8. Y. He, K. Yang, W. Sha, Z. Guo, and K. Liu: Metall. Mater. Trans. A, 2006, vol. 37A, pp. 1107-16.

9. R.D. Garwood and R.D. Jones: J. Iron Steel Inst., 1966, vol. 204, p. 512 .

10. E.V. Emchenko-Rybko, S.P. Oshkaderov, and R.V. Televich: Phys. Met., 1985, vol. 5, pp. 1119-25.
11. A. Shekhter, H.I. Aaronson, M.K. Miller, S.P. Ringer, and E.V Pereloma: Metall. Mater. Trans. A, 2004, vol. 35A, pp. 973-83.

12. S.-J. Kim and C.M. Wayman: Mater. Sci. Eng. A, 1990, vol. 128, pp. 217-30.

13. E.V. Emchenko-Rybko, S.P. Oshkaderov, R.V. Televich, and G. Ziss: Phys. Met., 1985, vol. 6, pp. 495-502.

14. V.G. Gavrilyuk, E.V. Emchenko-Rybko, V.M. Nadutov, S.P. Oshkaderov, and R.V. Televich: Phys. Met., 1990, vol. 9, pp. 191-98.

15. S.-J. Kim and C.M. Wayman: Mater. Sci. Eng. A, 1996, vol. 207, pp. 22-29.

16. E.V. Pereloma, A. Shekhter, M.K. Miller, and S.P. Ringer: Acta Mater., 2004, vol. 52, pp. 5589-5602.

17. T.F. Kelly, P.P. Camus, D.J. Larson, L.M. Holzman, and S.S. Bajikar: U.S. Patent Serial No. 08/272, 204, 1995.

18. M.K. Miller: in Handbook of Microscopy for Nanotechnology, N. Yao and Z.L. Wang, eds., Kluwer Academic Press, New York, NY, 2005, p. 742.

19. M.K. Miller: Atom Probe Tomography, Kluwer Academic/Plenum Press, New York, NY, 2000, pp. 28-197.

20. E.V. Pereloma, M.K. Miller, and I.B. Timokhina: Metall. Mater. Trans. A, 2008, vol. 39A, pp. 3210-16.

21. J. Kučera, B. Million, and K. Stránský: Kovové Materiály, 2003, vol. 41 , pp. $325-34$.

22. E. Navara and R. Harrysson: Scripta Metall., 1984, vol. 18, pp. $605-10$.

23. P. Klugkist and C. Herzig: Phys. Status Solidi A, 1995, vol. 148, pp. 413-21.

24. N.-H. Heo: Acta Mater., 1996, vol. 44, pp. 3015-23

25. R.-Y. Li, J.-Y. Qin, T.-K. Gu, and X.-F. Bian: J. Non-Cryst. Solids, 2008, vol. 354, pp. 1736-39.

26. Y.M. Kim, C.D. Yim, and B.S. Yum: Scripta Mater., 2007, vol. 57, pp. 691-94.

27. D.A. Squires and E.A. Wilson: Metall. Trans., 1972, vol. 3, pp. 575-81.

28. D.A. Squires, F.G. Wilson, and E.A. Wilson: Metall. Trans., 1974, vol. 5, pp. 2569-78.

29. D. Isheim, M.S. Gagliano, M.E. Fine, and D.N. Seidman: Acta Mater., 2006, vol. 54, pp. 841-49. 